\title{
STRATEGI BADAN EKSEKUTIF MAHASISWA (BEM) UNTUK MENCAPAI PROGRAM KERJA ORGANISASI DI UNIVERSITAS KADIRI
}

\author{
*Teguh Pramono ${ }^{1)}$, Suwarno ${ }^{2)}$, Sugeng Widodo ${ }^{3)}$ \\ 1) Program Studi Administrasi Publik, Fakultas Ilmu Sosial dan Ilmu Politik Universitas Kadiri, \\ Indonesia \\ 2) Program Studi Administrasi Publik, Fakultas Ilmu Sosial dan Ilmu Politik Universitas Kadiri, \\ Indonesia \\ 3) Program Studi Administrasi Publik, Fakultas Ilmu Sosial dan Ilmu Politik Universitas Kadiri, \\ Indonesia \\ *Email Korespondensi : tghpram@unik-kediri.ac.id
}

\begin{abstract}
Abstrak
Tujuan penelitian ini untuk mendeskripsikan dan menganalisis Organisasi Kemahasiswaan (BEM) dalam menyelesaikan masalah dalam rangka mewujudkan program kerja organisasi di Universitas Kadiri. Mendeskripsikan dan menganalisis faktor kendala dalam mewujudkan program organisasi. Mendasarkan pada karakter masalah maka penelitian ini menggunakan pendekatan kualitatif, dengan menggunakan teknik penentuan informan yaitu teknik purposive, dan 10 informan, Pengumpulan data dengan pendekatan wawancara, observasi dan dokumentasi. Agar data yang dikumpulkan teruji keabsahannya maka digunakan triangulasi data yaitu cek dan recek kemudian dikontrol dengan uji keabsahan data. Data yang telah terkumpul dianalisis dengan teknik analisis Interaktif dari Milles dan Huberman. Hasil penelitiannya sebagai berikut : Pertama Mahasiswa dalam menyelesaikan berbagai masalah yang dihadapi dalam pelaksanaan program kerja adalah dengan pendekatan kerjasama dari pada pendekatan perlawanan. Kedua, Kendala yang dihadapi dalam pelaksanaan program kerja adalah perbedaan kepentingan, padatnya perkuliahan dan sarana prasarana serta keterbatasan anggaran. Ketiga. Adapun kesimpulan yang diperoleh adalah Badan Eksekutif Mahasiswa dalam melaksanakan program kerja tergantung pada kondisi keuangan atau anggaran lembaga. Banyak persyarataan yang harus dipenuhi apabila BEM mencari sposor atau sumber biaya lain.
\end{abstract}

Kata Kunci: Kerjasama; Program Kerja; BEM

\begin{abstract}
The purpose of this study is to describe and analyze the Student Organization (BEM) in solving problems in order to realize the work program of the organization at the University of Kadiri. Describe and analyze the constraints factor in realizing the organization program. Basing on the character of the problem then this research using qualitative approach, using the technique of determining the informant that is purposive technic, and 10 informant, Data collecting by interview approach, observation and documentation. In order for data collected tested its validity
\end{abstract}


then used triangulation of data that is check and recheck then controlled by validity test data. The collected data were analyzed by Interactive analysis techniques from Milles and Huberman. The results of his research as follows: First Students in solving various problems encountered in the implementation of work programs is with a cooperative approach than the resistance approach. Second, the obstacles encountered in the implementation of the work program is the difference of interest, the density of lectures and infrastructure and budget constraints. Third. The conclusions obtained are the Student Executive Board in implementing the work program depending on the financial condition or the budget of the institution. Many statements must be met if BEM seeks out other sposors or sources of expenses.

Key Words: Teamwork; Work Plan; Executive Student Board

\section{PENDAHULUAN}

Sudah diketahui bersama bahwa setiap perguruan tinggi baik negeri maupun swasta memiliki perangkat organisasi kemahasiswaan. Organisasi kemahasiswaan itulah yang mewadahi seluruh kegiatan kemahasiswaan yang pembinaannya berada langsung dibawah wakil dekan bidang kemahasiswaan dan Pembantu Rektor bidang kemahasiswaan. Organisasi kemahasiswaan tersebut beranggotakan mahasiswa yang bertugas untuk mewadahi bakat, minat dan potensi mahasiswa yang dilaksanakan di dalam kegiatan ko dan ekstra kurikuler.

Mahasiswa, disamping menuntut ilmu pengetahuan dalam rangka bekal hidup di masa mendatang, baik secara pribadi maupun sosial, namun bekal kepandaian saja belumlah cukup untuk menyongsong kehidupan ke depan apalagi untuk memajukan bangsa dan negara. Apalagi dewasa ini persaingan antar bangsa dan antar negara sudah tidak terbendung lagi. Mahasiswa sebagai generasi penerus bangsa hendaknya memiliki bekal kepemimpinan, keorganisasian, pengalaman memecahkan berbagai masalah, kemampuan bernegosiasi, kemampuan berkoordinasi. Melalui kegiatan organisasi kemahasiswaa di kampus tempat belajar merupakan sebagai kawah condrodimuko seorang mahasiswa untuk menempa diri menjadi pribadi yang unggul, tidak hanya unggul kemampuan intekektualnya saja, kepribadiannya saja, melainkan juga unggul berorganisasi dan kepemimpinannya. Kepemimpinan di suatu organisasi perlu mengembangkan team dan membangun iklim motivasi yang menghasilkan tingkat kinerja yang tinggi (Marwanto, 2018). Jiwa kepemimpinan dapat dikembangkan yakni, 
pembinaan, pelatihan dan pengembangan, pemberdayaan dan partisipasi (Yanuarita et al., 2019)

Mahasiswa sebagai harapan bangsa dan negara untuk melanjutkan estafet kepemimimpinan, estafet pelaksanaan pembangunan, estafet memajukan bangsa dan negara sebagai penyambung lidah kepemimpinan bangsa dan negara, bekal sebbagaimana tersebut di atas mutlak harus dimiliki, agar tidak menjadi mahasiswa yang minim pengalaman, minim pengetahuan, minim pergaulan, yang akhirnya akan berujung pada ketidakpercayaan diri, sehingga tidak berani menghadapi berbagai tantangan, persoalan, mudah panik dan jika sudah demikian tidak bisa diandalkan baik secara pribadi, apalagi secara sosial kemasyarakatan.

Mahasiswa juga sebagai agen perubahan sosial (social of cahange), mengingat mahasiswa merupakan salah satu komponen pemuda yang selalu idealis sehingga menjadi dinamis terhadap segala hal, baik itu dalam kehidupan pribadi, sosial maupun budaya. Kemajuan suatu bangsa tergantung pada kedinamisan pemudanya. Mahasiswa sebagai salah satu bagian dari kaum muda dalam tatanan masyarakat yang mau tidak mau pasti terlibat langsung dalam tiap fenomena sosial, harus mampu mengimplementasikan kemampuan keilmuannya dalam akselerasi perubahan sosial budaya ke arah berkeadaban dan berkeadilan, jangan justru larut oleh keadaan.

Dalam setiap perubahan tatanan kenegaraan, ketidakpuasan rakyat terhadap pemerintah dikomandani oleh mahasiswa dan dalam setiap aksinya mahasiswa selalu terlibat, baik langsung maupun tidak langsung dan justru menjadi jargon dan pilar utama terjaminnya sebuah tatanan kenegaraan yang demokratis. Romantisme politis antara mahasiswa dengan rakyat terlihat sebagai fungsi social control. Harmonisasi politik antara mahasiswa dengan rakyat selama ini sebagai salah satu indikator dan potensi kekuatan politik yang dapat diandalkan dalam upaya menuju tatanan masyarakat yang berkeadilan, dan sewaktu-waktu dapat digerakkan dalam segala aspek kehidupan sosial. Peran mahasiswa sebagai social of changes dan social control selalu ditunggu dan diharapkan. Harapan masyarakat hendaknya mahasiswa mampu memainkan peran yang strategis tersebut. Dukungan sosial, budaya maupun ekonomi dan politik serta adanya 
kesatuan visi, tekad, dan perjuangan untuk kepentingan masyarakat secara luas, menjadi pondasi yang kokoh dari peran mahasiswa tersebut.

Mahasiswa sebagai social of changes dan social control sebagai ungkapan yang penuh spirit, penuh motivasi, dan pembakar semangat juga sebagai ungkapan kebanggaan masyarakat kepada mahasiswa mengandung makna cita-cita dan atau keinganan rakyat terhadap mahasiswa sebagai suatu komunitas yang perlu dibuktikan dan diwujudkan. Namun demikian untuk dapat mewujudkan harapan masyarakat terhadap mahasiswa tersebut tidaklah mudah, mengingat perlu adanya pemetaan, perumusan, dan penelaahan atau pengkajian ulang tentang metode penerapan fungsi mahasiswa dalam kancah epistemologi keumatan tersebut. Ironisnya, mencairnya gerakan mahasiwa ke dalam internal kampus tidak menjadikan organisasi kemahasiswaan tumbuh dan berkembang sebagai kekuatan social society dan memiliki bargaining posisioning dalam mensikapi kebijakan-kebijakan birokrasi kampus dan mengakomodir aspirasi dan menjadi juru bicara mahasiswa.

Organisasi kemahasiswaan yang dilahirkan oleh Keputusan Menteri Pendidikan dan Kebudayaan Republik Indonesia Nomor 155/U/1998 seharusnya menjadi organisasi yang militan yang berperan sebagai penyeimbang berbagai kebijakan dan keputusan birokrasi kampus yang kurang atau tidak berpihak pada mahasiswa justru menjadi lemah syahwat, tidak memiliki kekuatan social society dan bargaining position. Mengapa demikian, yang bisa menjawab itu tentunya adalah pengurus atau seluruh mahasiswa yang ada.

Kondisi objektif di lapangan adalah adanya ketidaksamaan persepsi mahasiswa tentang tujuan mereka kuliah, tentang makna sebagai mahasiwa, sehingga memunculkan dua kelompok mahasiswa, hal ini bukanlah salah, namun mengingkari makna mahasiswa sebagai generasi muda, mahasiswa sebagai generasi penerus, mahasiswa sebagai pemegang estafet kepemimpinan. Dua kelompk mahasiswa tersebut yaitu (1). Kelompok Mahasiswa Кири-kири (kuliah pulang-kuliah pulang). Tipikal dari individu atau kelompok mahasiswa ini dominan melewai hari-harinya di kampus full hanya dengan belajar “Teks Book”, mengerjakan semua yang diperintahkan setiap dosen (baca: dosen) 
dengan harapan kuliah dapat selesai tepat waktu dan meraih prestasi akademik yang memuaskan sehingga dapat menjadi dongkrak untuk peningkatan karier.

Mahasiswa yang aktif berorganisasi secara konsisten semata-mata memiliki pemahaman bahwa organisasi kemahasiswaan merupakan sebuah sarana yang efektif dalam mengkader dirinya sendiri untuk ke depan. Sebagian di antaranya masih mempunyai keyakinan pandangan bahwa kampus merupakan tempat menimba ilmu yang tidak terbatas hanya kepada pelajaran semata. Bergabung aktif dalam organisasi kemahasiswaan yang bersifat intra ataupun eksra kampus berefek kepada perubahan yang signifikan terhadap wawasan, cara berpikir, pengetahuan dan ilmu-ilmu sosialisasi, kepemimpinan serta menajemen kepemimpinan yang notabene tidak diajarkan dalam kurikulum normatif Perguruan Tinggi. Namun, dalam ber-organisasilah dapat diraih dengan memanfaatkan statusnya sebagai mahasiswa.

Berdasarkan hal tersebut maka organisasi mahasiswa dituntut untuk terus meningkatan kualiatas dirinya dan peningkatan pelayanan terhadap mahasiswa. Sebagai miniatur pemerintahan negara dalam penyelenggaraan negara yang semestinya dilakukan oleh aparatur negara. Komitmen peningkatan kualitas pelayanan dengan memperhatikan aspek-aspek komunikasi, psikologis dan perilaku dalam melayani, paradigma selalu dilayani dirubah menjadi gemar melayani (Mujiarto et al., 2019). Maka, organisasi mahasiswa harus mengadopsi prinsip-prinsip pemerintahan layaknya dalam sebuah negara dan dikolaborasikan dengan prinsip sebagai organisasi pengkaderan dan perjuangan.

Organisasi merupakan salah satu media yang dapat membentuk kematangan mahasiswa dalam hidup bermasyarakat ialah organisasi. Melalui organisasi maka mahasiswa akan senantiasa terus berinteraksi dan beraktualisasi, sehingga menjadi pribadi yang kreatif serta dinamis dan lebih bijaksana dalam persoalan yang mereka hadapi. Pada dasarnya, organisasi mahasiswa adalah sebuah wadah berkumpulnya mahasiswa demi mencapai tujuan bersama, namun harus tetap sesuai dengan koridor AD/ART yang disetujui oleh semua anggota dan pengurus organisasi tersebut. Organisasi mahasiswa tidak boleh keluar dari rambu-rambu utama tugas dan fungsi perguruan tinggi yaitu Tri 
Darma Perguruan Tinggi, tanpa kehilangan daya kritis dan tetap berjuang atas nama mahasiswa, bukan pribadi atau golongan.

Demikian juga dengan Universitas Kadiri, untuk organisasi kemahasiswaan memiliki Badan Eksekutif Mahasiswa (BEM) yang pembinaannya langsung dibawah pembantu rektor 3 bidang kemahasiswaan. Sebagaimana organisasi kemahasiswaan maka anggotanya adalah para mahasiswa, demikian juga dengan pengurusnya. Namun tidak semua dan segala lapisan mahasiswa bisa menjadi pengurus organisasi tersebut. Semua ada aturan main yang mengaturnya. Pengurus BEM di Universitas Kadiri dipilih setiap 1 tahun sekali dan terdiri dari dua departemen, yaitu departemen dalam negeri dan departemen luar negeri serta empat bidang.

Bidang minat dan bakat didalamnya terdapat departemen olahraga dan seni budaya, departemen pengabdian pada masyarakat, bidang informasi dan komunikasi, serta departemen pendidikan dan penelitian. Semua departemen dan olahrga tersebut memiliki anggota atau pengurus yang dipilih setiap 1 tahun sekali. Setiap departemen maupun bidang mengembangkan segala kemampuan dan potensinya untuk ikut serta memajukan program-program kampus, khususnya dibidang kemahasiswaan.

Organisasi kemahasiswaan dalam hal ini Badan Eksekutif Mahasiswa juga bertindak sebagai kontrol terhadap jalannya civitas akademika yang dipandang menyimpang atau tidak adil menurut pandangan mahasiswa. Maka BEM dapat bertindak kritis dan korektif terhadap kampus, baik itu rektorium ataupun dekanat. Tindakan kritis dan korektif tersebut perlu dilakukan untuk menegakkan kembali jalannya proses akademik yang sekiranya menunjukkan gejala-gejala menyimpang.

Keikutsertaan organisasi kemahasiswaan (BEM) Universitas Kadiri dalam setiap kegiatan di luar kampus atau antar kampus menjadi kegiatan rutin yang sudah terjadwal dalam organisasi sebagai perwujudan kerjasama antar BEM dengan perguruan tinggi lain, saling berkompetitif secara sehat dalam rangka meraih prestasi. Oleh karena itu semangat berjuang untuk terus berprestasi tidak boleh kendur atau diciderai oleh virusvirus yang dapat melemahkan motivasi mahasiswa untuk berprestasi baik dibidang akademik maupun keorganisasian. Adapun yang menjadi persoalan adalah bagaimana Organisasi 
Kemahasiswaan menyelesaikan berbagai masalah dalam rangka mewujudkan Program Organisasi di Kampus Universitas Kadiri.

\section{TINJAUAN PUSTAKA}

Mahasiswa ditinjau dari fungsinya terhadap kampus maupun terhadap bangsa dan negara memiliki tiga fungsi utama, yaitu sebagai agent of change, social control and iron stock. Berdasarkan fungsi mahasiswa tersebut, maka dapat dijelaskan bahwa mahasiswa memiliki fungsi yang sangat berat sebagai orang yang masih belum banyak pengalaman tetapi berdasarkan ide-idenya memang mahasiswa sebagai generasi muda memang mempunyai tugas dan tanggungjawab yang tidak ringan untuk membenahi dan memajukan bangsa dan negara ini.

Fungsi mahasiswa bukan hanya belajar, namun melalui berbagai ide, pikiran kritis yang disumbangkan melalui berbagai forum ilmiah mampu menjadi bahan pertimbangan atau kadang merubah berbagai aturan atau tatanan yang dirasa tidak berkeadilan terhadap kondisi masyarakat. Oleh karena itu mahasiswa tidak bisa acuh tak acuh terhadap kondisi masyarakat, karena mahasiswa sebagai suatu komunitas juga merupakan bagian dari masyarakat. Fungsi inilah yang harus dikembangkan oleh mahasiswa dan untuk itu perlu wadah yang berupa organisasi. Melalui berbagai pikiran atau sumbangan ide yang kadang mendobrak tatanan perlu juga dipertimbangkan oleh pengambil kebijakan.

Disisi lain mahasiswa sebagai kontrol bagi masyarakat dan terhadap penyelenggara negara baik itu eksekutif, yudikatif maupun legislatif. Kontrol dimaksud melalui ide dan pikiran kritisnya juga perlu dipertimbangkan jika dirasa perlu dan mengandung pembenaran dan perubahan masyarakat tersebut. Mungkin kondisi yang terjadi tidak menguntungkan masyarakat, tidak mengandung unsur keadilan dan atau tidak berpihak pada masyarakat. Apa yang dipaparkan di atas tentang ketimpangan dan tidak mengandung unsur berkeadilan berbagai kritik dan saran serta berbagai kegiatan mahasiswa agar tidak menjadi liar dan emosional serta anarkis maka perlu wadah atau berbagai fasilitas yang kemudian disebut organisasi mahasiswa.

Disadari atau tidak bahwa mahasiswa merupakan calon pemimpin dimasa depan. Oleh karena itu tidak berlebihan kiranya jika dikatakan bahwa maju mundurnya suatu 
bangsa dan negara berada dipundak pemuda. Sebagai calon pemimpin (iron stock), mahasiswa tidak cukup hanya berbekal kepandaian saja, hanya berbekal ilmu pengetahuan yang spesifik saja, melainkan harus berbekal ilmu pengetahuan yang lengkap, misalnya kepemimpinan, keorganisasiaan, kepekaan sosial terhadap kehidupan rakyat, kemampuan berorasi, kemampuan berpolitik, dan berbagai kemampuan lain yang terkadang tidak diperoleh dibangku perkuliahan. Oleh karena itu mahasiswa tidak selayaknya hanya datang masuk kuliah terus pulang.

Menyadari itu semua maka dapat diartikan bahwa pengembangan kehidupan kemahasiswaan adalah bagian integral dalam sistem pendidikan nasional sebagai kelengkapan kegiatan kurikuler. Wadah dimaksud adalah organisasi kemahasiswaan dan hal tersebut harus terus ditingkatkan peranannya sebagai perangkat perguruan tinggi dan sebagai warga civitas akademika. Dimasa mendatang pengembangan organisasi kemahasiswaan perlu disesuaikan dengan pelaksanaan reformasi dibidang pendidikan tinggi dan tuntutan globalisasi. (Pertimbangan Keputusan Menteri Pendidikan dan Kebudayaan Republik Indonesia Nomor 155/U/1998). Keputusan tersebut mengartikan Organisasi kemahasiswaan intra perguruan tinggi adalah wahana dan sarana pengembangan diri mahasiswa ke arah perluasan wawasan dan peningkatan kecendekiawanan serta integritas kepribadian untuk mencapai tujuan pendidikan tinggi.

Bab I pasal 1 Keputusan Menteri Pendidikan dan Kebudayaan Republik Indonesia Nomor 155/U/1998, lebih jauh menguraikan bahwa "kegiatan kurikuler adalah kegiatan akademik yang meliputi : kuliah, pertemuan kelompok kecil (seminar, diskusi, responsi), bimbingan penelitian, praktikum, tugas mandiri, belajar mandiri, penelitian dan pengabdian kepada masyarakat (kuliah kerja nyata, kuliah kerja lapangan dan sebagainya). Kegiatan ekstrakurikuler adalah kegiatan kemahasiswaan yang meliputi: penalaran dan keilmuan, minat dan kegemaran, upaya perbaikan kesejahteraan mahasiswa dan bakti sosial bagi masyarakat (tentang Pedoman Umum Organisasi Kemahasiswaan di Perguruan Tinggi. Jakarta).

Organisasi intra dimaksud dalam pasal 1 tersebut adalah Badan Eksekutif Mahasiswa. Adapun yang dimaksud dengan BEM adalah organisasi mahasiswa intra kampus yang merupakan lembaga eksekutif di tingkat Universitas/Institut/Sekolah 
Tinggi. Dalam melaksanakan program-programnya, umumnya BEM memiliki beberapa departemen." BEM menjadi wadah dari seluruh mahasiswa untuk mengembangkan bakat dan kemampuan yang dimiliki agar menjadi mahasiswa yang memiliki kekayaan di bidang ilmu pengetahuan, kesenian dan lain sebagainya. BEM sebagai jembatan penghubung antara mahasiswa dan lembaga, jadi BEM berfungsi sebagai sarana mahasiswa untuk menyalurkan sumbang saran dan aspirasinya kepada pihak lembaga untuk mewujudkan kesejahteraan di lingkungan kampus.

Tugas pokok organisasi BEM antara lain (1) mengajukan proposal kegiatan kepada pimpinan fakultas maupun universitas serta membuat laporan pertanggungjawaban terhadap kegiatan yang sudah dilaksanakan, (2) pembuat program kegiatan sesuai dengan aturan yang berlaku, (3) membimbing dan melakukan pengawasan terhadap kegiatan UKM (Unit Kegiatan Mahasiswa). (4) sebagai duta perguruan tinggi untuk berkomunikasi dengan perwakilan mahasiswa dari perguruan dalam kegiatan eksternal dengan BEM lain, (5) menampung dan memperjuangkan kepentingan mahasiswa baik akademik maupun aspek lain, (6)

Sesuai dengan bab II pasal 3 Keputusan Mendikbud, 1998 bahwa setiap perguruan tinggi hanya ada satu organisasi intra (BEM) yang menaungi semua aktivitas kemahasiswaan dan sampai pada level fakultas dan jurusan. Jika dikaji sampai pada penyusunan struktur organisasinya maka Bentuk dan badan kelengkapan organisasi kemahasiswaan intra perguruan tinggi ditetapkan berdasarkan kesepakatan antar mahasiswa, tidak bertentangan dengan peraturan perundang-undangan yang berlaku, dan statuta perguruan tinggi yang bersangkutan. BEM juga boleh menggali dukungan dana dari luar kampus, namun syaratnya yang tidak mengikat (dukungan dana diberikan tanpa syarat).

Walgito (2003:65) menyatakan interaksi sosial merupakan suatu hubungan yang saling timbal balik. Menurut Bonner (dalam Gunawan, 2010:31) interaksi sosial merupakan suatu hubungan antara dua orang atau lebih, sehingga kelakuan individu yang satu mempengaruhi, mengubah, atau memperbaiki kelakuan individu yang lain, dan sebaliknya. Wulansari (2009:39-40) berpendapat bahwa bentuk-bentuk interaksi sosial ialah kerjasama, pertikaian (kerjasama negatif), persaingan, dan akomodasi. 
Negosiasi adalah sebuah bentuk interaksi sosial saat pihak-pihak yang terlibat berusaha untuk saling menyelesaikan tujuan yang berbeda dan bertentangan (Tan \& Lim, 2004). Menurut kamus Oxford, negosiasi adalah suatu cara untuk mencapai suatu kesepakatan melalui diskusi formal. Negosiasi merupakan suatu proses saat dua pihak mencapai perjanjian yang dapat memenuhi kepuasan semua pihak yang berkepentingan dengan elemen-elemen kerjasama dan kompetisi (termasuk di dalamnya, tindakan yang dilakukan ketika berkomunikasi, kerjasama atau memengaruhi orang lain dengan tujuan tertentu) (Kozicki, 2005).

Proses accommodation ini menuju pada suatu tujuan yang mencapai kestabilan (Bungin, 2006: 60-61). Istilah akomodasi berasal dari kata accommodation yang berarti penyesuaian diri. Secara luas, akomodasi berarti suatu bentuk proses sosial yang di dalamnya ada dua atau lebih individu atau kelompok berusaha untuk saling menyesuaikan diri, tidak saling mengganggu dengan cara mencegah, mengurangi, atau menghentikan ketegangan yang akan timbul atau yang sudah ada sehingga tercapai kestabilan (keseimbangan).

\section{METODE PENELITIAN}

Penelitian ini ingin mencoba menemukan model penyelesaian masalah atau ketidak sepahaman atau perjuangan mahasiswa dalam memecahkan berbagai persoalan dengan pihak pembina tanpa harus ada merasa yang dikalahkan. Oleh karena itu permasalahan dalam penelitian ini adalah (1). Bagaimana Organisasi Kemahasiswa menyelesaikan berbagai masalah dengan pembina dalam rangka mewujudkan Program Organisasi di Kampus Universitas Kadiri. (2). Faktor apa yang menjadi kendala BEM dalam mewujudkan Program Organisasi. Adapun yang menjadi tujuan penelitian ini adalah (1). Mendeskripsikan dan menganalisis Organisasi Kemahasiswaan (BEM) dalam menyelesaikan masalah dalam rangka mewujudkan program kerja organisasi di Universitas Kadiri. (2) Ingin mendeskripsikan dan mengnalisis faktor kendala dalam mewujudkan program organisasi. Pendakatan penelitian dengan pendekatan penelitian kualitatif dan teknik pengumpulan data wawancara, observasi partisipasi dan dokumentasi 
serta teknik analisis dengan teknik analisis interaktif dari Miles dan Huberman dalam (Saldana, 2014).

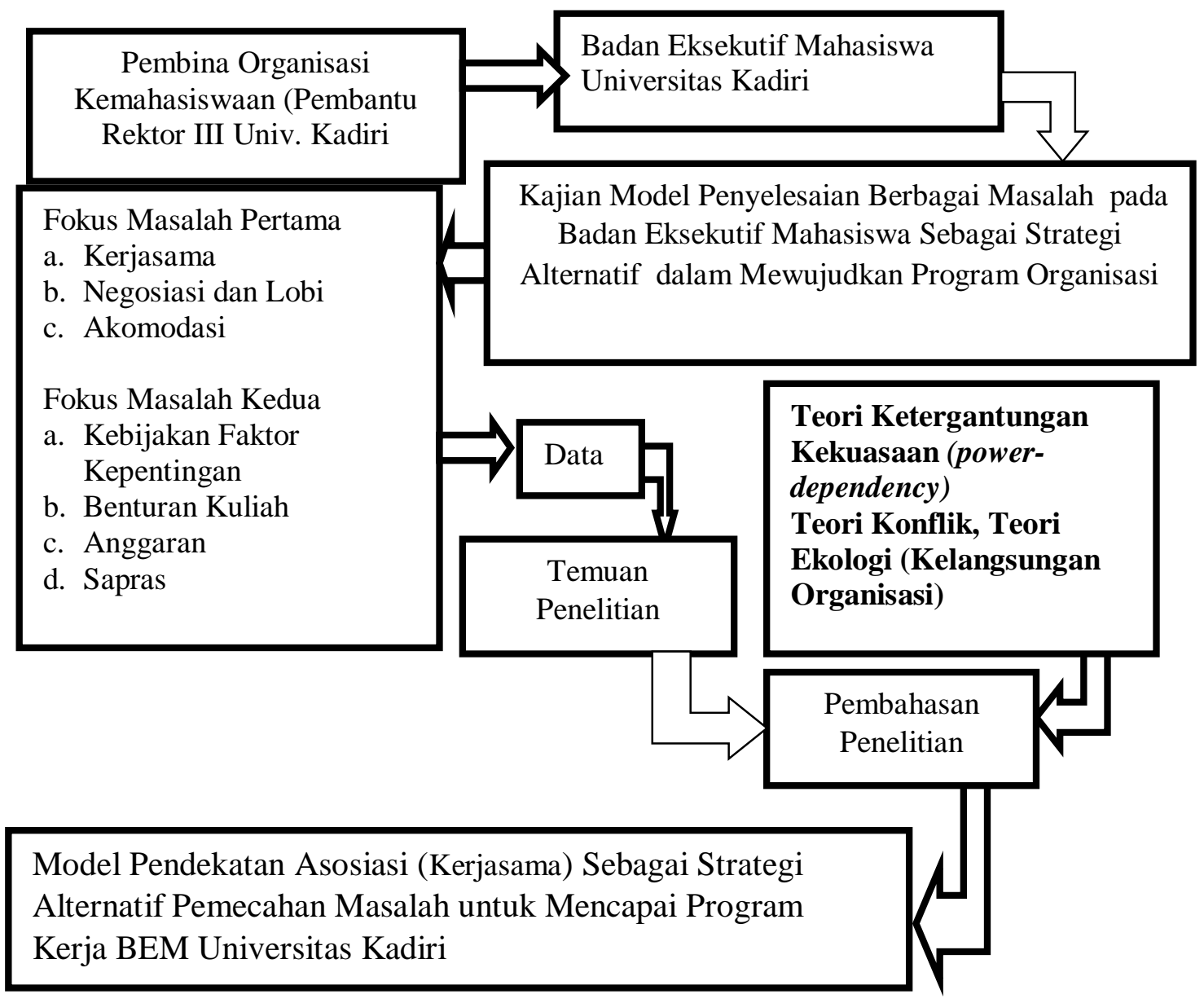

\section{Gambar 1. Kerangka Alur Penelitian}

Kajian ini dilakukan dengan mendasarkan pada pembangunan di segala bidang pada umumnya dan pembangunan kemahasiswaan yang merupakan generasi penerus bangsa. Kampus sebagai wadah penggemblengan mahasiswa yang dilengkapi dengan berbagai media guna untuk menggembleng, belajar dan media baik secara ilmu pengetahuan, sosial, ekonomi, politik maupun penanaman budaya luhur bangsa Indonesia. Kampus modern bukan hanya sebagai sumber ilmu pengetahuan saja, melainkan kampus modern adalah sebagai wadah pusat berlatih, pusat belajar, pusat latihan, pusat penggemblengan, pusat aktivitas para generasi muda (dalam hal ini adalah mahasiswa) juga pusat kebudayaan. Menyadari tentang hal tersebut di atas, maka organisasi bagi 
mahasiswa memiliki fungsi untuk media latihan keorganisasian, yang kelak dikemudian hari memiliki peran penting dalam kepemimpinan mahasiswa, baik itu sosial, politik, maupun budaya.

Agar dapat diungkap tentang bagaimana mahasiswa memaknai organisasi kemahasiswaan di kampus dan kaitannya dengan akademik, maka pendekatan penelitiaan yang digunakan adalah pendekatan kualitatif. Pemilihan metode kualitatif dengan pertimbangan metode kualitatif memiliki keunggulan, antara lain lebih melihat proses daripada produk dari objek penelitiannya, serta sebagai upaya pemahaman penelitian perilaku dan penelitian motivasional.

Adapun yang menjadi objek utama dalam penelitian ini adalah mahasiswa yang menjadi pengurus di BEM, adapun pembina organisasi kemahasiswaan di tingkat rektorium dan fakultas sebagai informan pendukung, dan teknik pemilihan informan dengan teknik purposive yaitu teknik pemilihan informan yang bertujuan, sehingga jumlah informan menjadi 10 informan yang masing-masing berfungsi untuk control (Teknik purposive). Mengingat penelitian kualitatif merupakan penelitian yang bertolak dari asumsi tentang realitas sosial yang bersifat unik dan kompleks, dan penuh dengan variasi. Oleh karena itu data ditelusuri seluas-luasnya sesuai dengan variasi yang ada, sehingga deskripsi tentang fenomena yang diteliti dapat berlangsung secara utuh.

Agar data yang dikumpulkan dapat dijamin keabsahannya, maka dipergunakan 4 kriteria keabsahan data sebagaimana yang diperkenalkan oleh (Flick, 2013) yaitu kriteria : (1) credibility (derajat kepercayaan) yang meliputi alokasi waktu yang cukup di lapangan, melakukan triangulasi, memperkuat referensi, serta pengecekan temuan penelitian; (2) transferability (keteralihan) yang meliputi penggunaan sampel secara memadai, membandingkan data secara konstan, mencari kejadian empiris tentang kesamaan konteks; (3) dependability (kebergantungan) melalui pemeriksaan data lapangan, reduksi data, analisis dan interpretasi data; (4) confirmability (kepastian) melalui pengumpulan data, diskusi dengan subyek penelitian, memperhatikan etika penelitian dan pengecekan kembali hasil data yang dikumpulkan. Secara rinci proses pengumpulan data dapat dijelaskan sebagai berikut: 
a) Observasi partisipasi (Partisipant Observer)

Pengamatan terhadap pengurus BEM dalam melaksanakan kegiatan tentang kebijakannya, himbauannya dan tindakannya dalam menjumpai masalah, menginventaris masalah dan menyelesaikan masalah tersebut. Pengamatan dilakukan secara partisipatif, yaitu peneliti tinggal di lokasi penelitian secara kontinyu selama beberapa hari dan hal itu secara berulang kali.

b) Wawancara

Wawancara dilakukan untuk menggali informasi tentang tanggapan atau respon serta alasan-alasan mahasiswa dalam mempertahankan programnya. Wawancara mendalam dilakukan dengan teknik dialog atau bincang-bincang (yang bertujuan untuk mengkonfirmasikan berbagai informasi yang disimpulkan sementara oleh peneliti atau responden. Agar data yang diperlukan dapat diperolah, maka masyarakat yang menjadi informan mewakili unit kerja dalam masyarakat sehingga informasi yang diperoleh tetap terjaga kualitasnya dan sesuai standart kredibilitas, transferabilitas, dan dipendabilitas serta konfirmabilitas yang dipersyaratkan dalam penelitian kualitatif.

c) Dokumentasi

Pengumpulan data penelitian tidak cukup hanya melalui wawancara dan observasi saja, melainkan juga perlu dilengkapi dengan data dokumentasi, dalam hal ini adalah hasil observasi dan wawancara tersebut perlu ada gambar yang dapat menceritakan atau memperjelas situasi, dan kondisi pada saat melakukan pengumpulan data (wawancara dan observasi). Oleh karena itu peranan foto atau rekaman video sangat diperlukan dalam rangka membantu memperjelas situasi dan kondisi di lapangan.

Menurut Patton yang dikutip Moleong, (2014) analisis data adalah proses mengatur urutan data, mengorganisasikannya ke dalam suatu pola, kategori, dan satu uraian dasar. Mengingat pendekatan penelitian ini adalah pendekatan kualitatif, maka antara kegiatan pengumpulan data dan analisis data tidak mungkin dipisahkan satu sama lain, berlangsung simultan atau serempak dan terus menerus (Saldana, 2014), sebelum, selama dan sesudah pengumpulan data, berikut diagram analisis data 


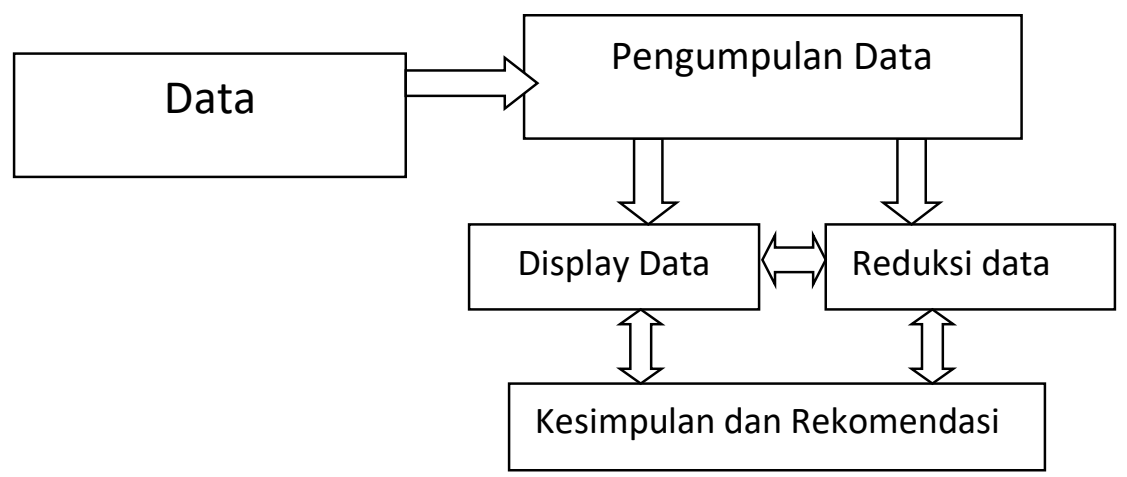

Gambar 2. Analisis Data Interaktif

Sumber Miles dan Hubberman dalam Saldana (2014)

\section{HASIL DAN PEMBAHASAN}

Proses pembelajaran di kampus sudah tentu didukung dengan ruang perkulihan, hal tersebut sesuai dengan pertumbuhan mahasiswa dan tuntutan kurikulum. Dukungan gedung-gedung perkuliahan yang lama masih proporsional dan yang baru terus dilakukan perencanaan dan demikian juga dengan pembangunan fasilitas laboratorium sesuai dengan bidang ilmu yang ditekuni. Berikut gedung-gedung yang berdiri di Kampus Ceria : Gedung A, Gedung B, Gedung D, Tempat Ibadah, gedung laboratorium, Audotorium, dan lain sebagainy.

Dalam menghadapi persainga antar perguruan tinggi baik negeri maupun swasta, dan juga sebagai upaya peningkatan pelayanan terhadap mahasiswa dan agar lebih dikenal oleh masyarakat luas, dan mempermudah akses sosial. Universitas Kadiri berusaha melakukan standardisasi peralatan teknologi informasi, pengoperasian, pemeliharaan jaringan, dan penyediaan akses berkecepatan tinggi ke jaringan lokal dan global yang saat ini didukung juga oleh jaringan fiber optik TELKOM. Seluruh area kampus dilengkapi dengan hotspot yang memanjakan sivitas akademika untuk mengakses sumber-sumber internet secara nirkabel.

Indikator kemajuan kampus tidak hanya dilihat dari prestasi dibidang pembelajaran, penelitian, pengabdian pada masyarakat, kemampuan dosen maupun mahasiswa saja. Namun juga bisa dicermati dari prestasi olahraga yang diperoleh 
mahasiswa. Prestasi olahraga tersebut bisa dicapai tentunya tidk lepas dari dukungan fasilitas olahraga yang dimiliki. Berikut berbagai fasilitas dan dukungan olahraga yang dimiliki oleh Universitas Kadiri di Kediri gedung olah raga, bias digunakan untuk basket, bulu tangkis, sepak takraw, dan tenes meja, serta beberapa lapangan bola volley. Secara rinci struktur organisasi BEM Universitas Kadiri periode 2016/2017 sebagai berikut.

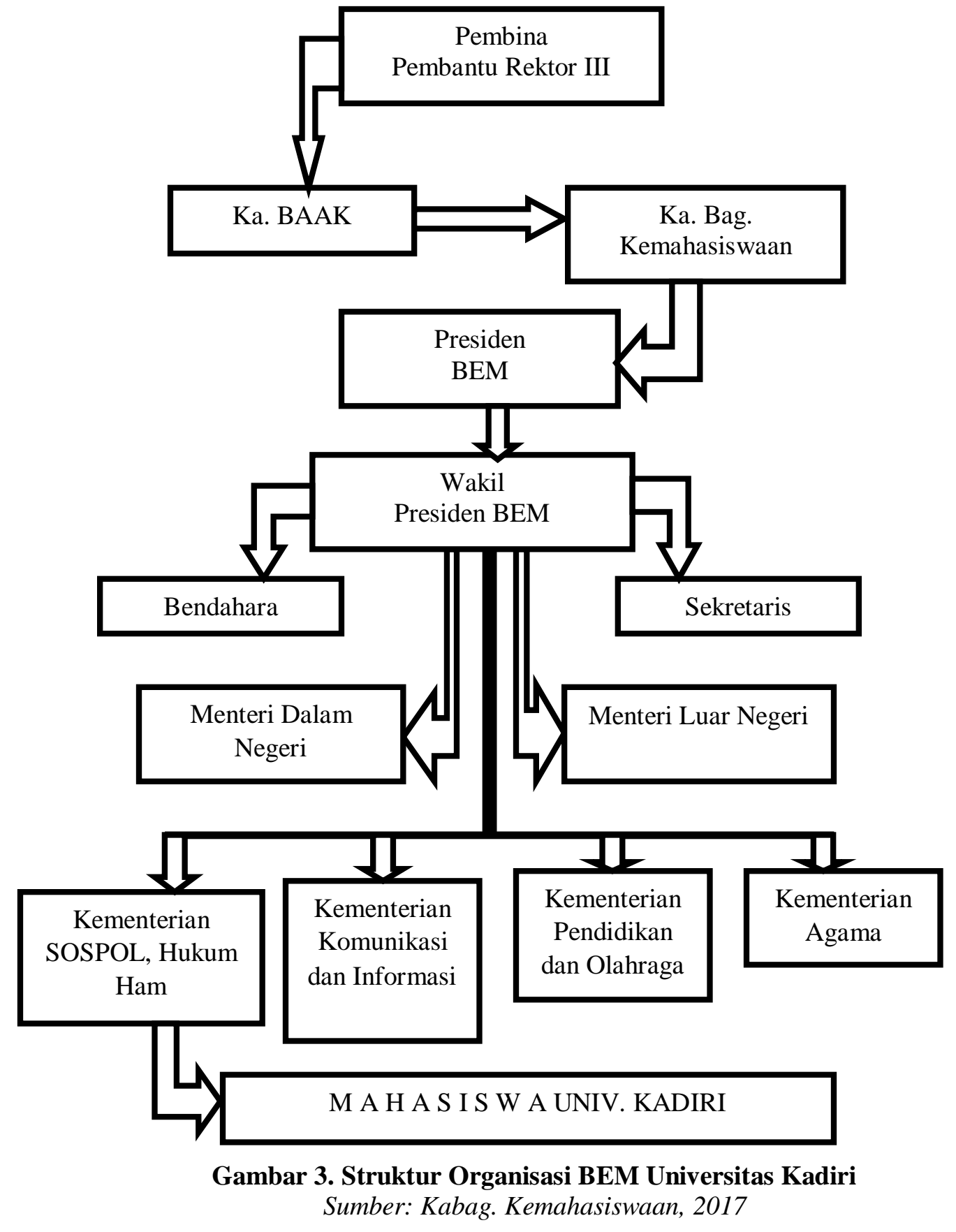


Di dalam struktur organisasi BEM di Univ. Kadiri terbagi dalam dua kemenetrian, yaitu mentri luar negeri dan mentri dalam negeri. Selanjutnya Kementerian luar negeri bersama anggotanya berkumpul guna membicarakan pelaksanaan program kerja. Dalam melaksanakan rencana program kerja, hendaknya harus ada kesepakatan tentang program kerja apa saja yang akan dilaksanakan. Kemudian hal tersebut dibicarakan internal di kementerian, yang kemudian jika sudah disetujui dilanjutkan ke rapat pleno organisasi. Hasilnya adalah proposal pelaksanaan yang dikirim ke rektorat. Jika disetujuai siap untuk dilaksanakan sesuai dengan anggaran yang telah ditetapkan, namun jika tidak, turun lagi ke kementrian agama untuk diperbaiki. Setelah itu dikirim kembali ke rektorat, jika disetujui dilaksanakan sesuai anggaran yang telah ditetapkan dan setelah selesai harus membuat laporan pelaksanaan dan laporan kerja. Berikut bentuk perjalanan usulan kegiatan oleh unit kegiatan mahasiswa di kementrian agama.

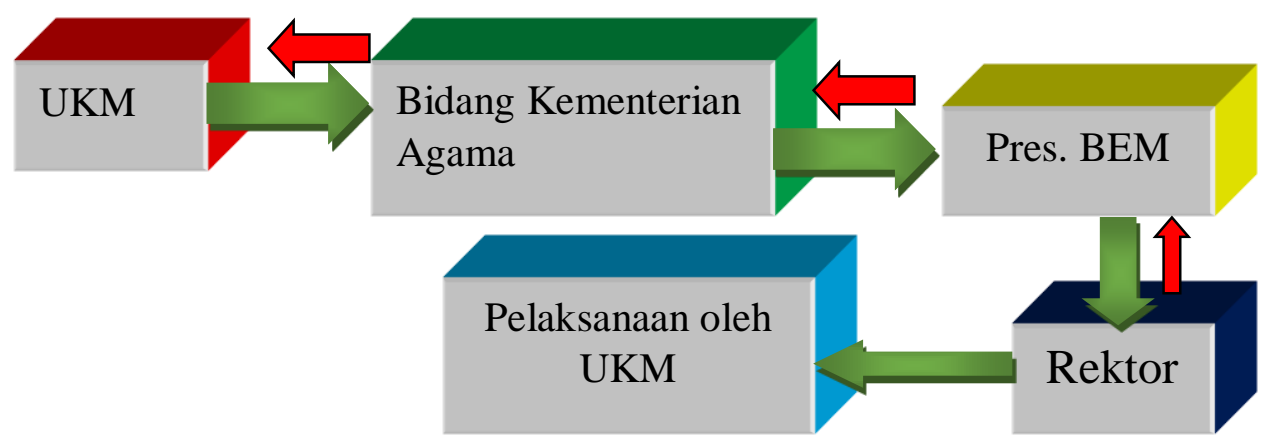

\section{Gambar 4. Alur Birokrasi Unit Kerja Mahasiswa Univ. Kadiri} Sumber: Olahan Peneliti, 2019

Adapun Program Kerja Kementerian Olahraga yang berhasil dilaksanakan, antara lain melaksanakan kegiatan olahraga khususnya dalam rangka menyambut Dies Natalis Kampus. Jenis olahraga yang dipertandingkan antara lain Bola Volly, Basket, Pencak silat, Bulutsngkis, dan tenis meja. Memfasilitasi Pekan Olahraga Fakultas Kesehatan se Jawa Timur, dan jenis olahraga yang difasilitasi, antara lain, Volly ball, bulutangkis, tenis meja, catur, dan regu catur dari FIK Uniersitas Kediri juara 2.

Setiap pelaksanaan suatu kegiatan sudah tentu adanya faktor yang mendukung dan faktor kendala, tinggal bagaimana panitia tersebut meminimalisir faktor kendala tersebut menjadi suatu potensi yang bisa dikembangkan. Berbagai faktor yang berpengaruh dalam 
menjalankan program kerja, antara lain dapat menjalankan tugas sesuai bidangnya dengan baik, tersedianya anggaran dana, tersedianya sarana dan prasarana.

Program kerja bidang kementerian sosial yang terlaksana antara lain sebagai berikut :

a. Seminar wawasan sosial budaya dan politik di lingkup kampus.

b. Avokasi dan pendampingan pada korban bencana alam.

c. Pendampingan pada masyarakat yang termarjinalkan oleh penguasa.

d. Bakti sosial

e. Pengarahan dan pelantikan tentang menteri sosial

Faktor yang Berpengaruh Keberhasilan program kerja

a. Partisipasi dari masing-masing anggota.

b. Semangat yang tinggi dalam melaksanakan kegiatan

c. Kekompakan

d. Tugas yang dilaksanakan tepat waktu

e. Penyampaian informasi tentang suatu kejadian yang berkaitan dengan BEM, cepat

f. Pembagian tuggas dilakukan secara jelas.

Berbagai Upaya BEM Menyelesaikan Berbagai Masalah dalam rangka mewujudkan Program Organisasi di Kampus Universitas Kadiri.

a. Kerjasama: Setiap kegiatan yang dilakukan oleh pengurus BEM selalu berprinsip kerjasama. Kerjasama tersebut terjadi sejak menysun perencanaan program kerja, tahapan yang harus dilalui dalam mengajukan proses pelaksanaan program kerja, pelaksanaan sampai dengan menyusun laporan kegiatan atau laporan pertanggungjawaban. Hal tersebut tampak pada kegiatan dari setiap kementerian yang ada di pengurus BEM di Universitas Kadiri.

b. Negosiasi atau Lobi, Mahasiswa (BEM) selama ini tidak pernah konfrontatif dalam memberikan argumentasi, hal tersebut tidak ada untung dan manfaatnya, sehingga lebih baik menggunakan pendekatan persuasif dan mencoba untuk memberikan argumen yang bisa diterima baik oleh lembaga maupun mahasiswa itu sendiri. Kekuatan negosiasi terletak pada tujuan, yaitu dalam rangka untuk memajukan kampus. Mengingat kemajuan kampus tidak hanya terletak pada 
berbagai prestasi dosen dalam pelaksanaan dan atau keerhasilan penelitian saja, namun juga pada peran dan kontribusi mahasiswa.

c. Akomodasi, adapun tujuan diadakan proses akomodasi, yaitu untuk menyelesaikan suatu permasalahan, mengurangi pertentangan karena perbedaan paham, memungkinkan terciptanya kerja sama antara kelompok yang hidupnya terpisah karena budaya, mencegah meledaknya suatu pertentangan, kelompok sosial yang terpisah dapat melebur menjadi satu. Jadi bentuk-bentuk penyelesaian masalah yang dilakukan oleh BEM Universitas Kadiri, antara lain : konsiliasi, toleransi.

Dalam rangka memperlancar dan dapat melaksanakan kegiatan yang sudah tertuang dalam program kerja BEM, maka BEM melakukan berbagai pendekatan terhadap berbagai pihak kuhususnya kepada pembina BEM yaitu Pembantu Rektor III, dengan mengajukan proposal, menjelaskan pentingnya dan manfaat kegiataan, bermusyawarah, mendengarkan arahan dan masukan sampai kemudian diputuskan untuk dilaksanakan.Hal ini disadari bahwa penyandang dana adalah lembaga (kampus)yang disalurkan atas persetujuan Pembantu Rektor III melalui bagian kemahasiswaan.

Teori ketergantungan muncul pemahaman akan keseimbangan dan kesetaraan, yang pada akhirnya membentuk sebuah pemberdayaan (empowerment) dalam partisipasi masyarakat dikenal sebagai teori keadilan. Sebagai contoh : Teori "ketergantungankekuasaan” (power-dependency) mengatakan kepada kita bahwa pemberi dana (donor) memperoleh kekuasaan dengan memberikan uang dan barang kepada masyarakat yang tidak dapat membalasnya. Hal ini memberikan ide bahwa lembaga/organisasi (non profit organization)/BEM sebaiknya tidak menerima dana dari hanya satu donor jika ingin merdeka/bebas. Masalahnya adalah sisteerm operasional prosedur di kampus mengijinkan atau tidak, tentunya banyak aturan atau persyaratan yang harus dipenuhi.

Pemberi dana (siapapun dia) menurut teori ketergantungan memiliki kekuasaan untuk mengendalikan, menguasai, dan memaksa untuk melakukan sesuatu. Melalui dana yang diberikan tertancap kuku kekuasaan yang harus diikuti dan dilakukan oleh yang diberi kuasa. Mengingat dana sebagai kunci utama untuk bisa melaksanakan program 
kerja. Jika penerima dana merasa dilecehkan, atau tertekan kemudian tidak bersedia melaksanakan, maka terjadi konflik.

Pada teori ekologi, membahas tentang organisasi sebagai wadah untuk sekumpulan masyarakat dengan tujuan yang sama agar tertatur, jelas, dan kuat. Orientasi organisasi mengacu pada sekumpulan orang/massa yang harus dimiliki kelompok untuk dapat memiliki power/daya. Kelompok yang memiliki organisasi dengan kuat dan berkelanjutan maka kelompok ini dikatakan berdaya. Dalam posisi teori ini BEM sebagai suatu organisasi kemahasiswa yang memiliki anggota yang terikat dalam anggaran dasar dan anggaran rumah tangga yang dikuatkan dalam suatu keputusan, memiliki kedudukan yang kuat dalam setiap pelaksanaan kegiatan. BEM bisa mengerahkan anggota (dalam hal ini adalah mahasiswa) untuk setiap kegiatan, BEM memiliki daya dan hal tersebut sebagai nilai tawar (bargaining velue).

Pandangan teori konflik mengacu pada dua aspek, yang pertama tentang ekonomi/uang yaitu berkaitan dengan modal sebagai sarana untuk kelompok dapat dikatakan berdaya dan mandiri. Aspek kedua menyangkut tentang organisasi, apabila kelompok dapat memanajemen konflik dengan baik, maka keutuhan dan kekuatan organisasi/kelompok orang akan terus kuat dan lestari sehingga mereka akan memiliki daya dari sisi finansial dan sisi keanggotaan massa.

Semua kembali pada tujuan awal atau anggaran dasar dan anggaran rumah tangga organisasi. Namun demikian azaz akomodasi selalu dikedepankan jika setiap terjadi permasalahan. Mengingat memang organisasi kemahasiswa merupakan organisasi tempat berlatih, menimba ilmu pengetahuan, tempat belajar berorganisasi, bukan sebagai suatu lembaga organisasi massa pada umumnya. Mengingat mahasiswa di kampus tidak hanya sekedar mengembangkan kecerdasan saja, namun juga mengembangkan kecerdasan sosialnya.

Akomodasi adalah usaha-usaha manusia untuk meredakan suatu pertentangan. Akomodasi dilakukan dengan tujuan tercapainya kestabilan dan keharmonisan dalam kehidupan. Akomodasi merupakan salah satu cara penyesuaian diri untuk menyelesaikan pertentangan/konflik tanpa menghancurkan pihak lawan atau mengorbankan salah satu pihak. (toleration), Stalemate, Tujuan akomodasi dapat berbeda-beda sesuai dengan 
situasi yang dihadapinya, yaitu untuk mengurangi perbedaan paham, mencegah terjadinya ledakan konflik, untuk memungkinkan terjadinya kerja sama antara kelompok-kelompok sosial, dan mengupayakan terjadinya proses pembauran antarsuku. Hasil akomodasi menurut Gillin dan Giliin yaitu akomodasi berperan besar dalam Integrasi masyarakat, akomodasi mampu menekan oposisi agar meredakan konflik, akomodasi dapat mengkoordinasi berbagai kepribadian yang berbeda yang dimiliki oleh berbagai pihak, akomodasi dapat menyebabkan perubahan lembaga-lembaga kemasyarakatan agar sesuai dengan dengan keadaan baru atau keadaan yang berubah, dan akomodasi menyebabkan perubahan-perubahan dalam kedudukan strata sosial.

Dalam setiap terjadi permasalahan, pertentangan, perdebatan yang mengarh kepada konflik, maka mahasiswa yang tergabung dalam organisasi Mahasiswa (BEM) selalu mengedepankan azaz kerjasama, negosiasi, dan akomodasi. Sudah disadari oleh pengurus BEM bahwa pemegang dana adalah lembaga (Kampus) maka permasalahan yang sering terjadi adalah benturan dengan kebijakan faktor kepentingan. Namun semua itu dikembalikan kepada azaz kerjasama, negosiasi, dan akomodasi, yang penting program kerja dapat dilaksanakan. Apabila tetap tidak bisa dilaksanakan, maka program kerja tersebut dibekukan untuk sementara waktu sampai dengan situasi dan kondisi mengijinkan. Strategi yang digunakan oleh pengurus BEM Universitas Kadiri agar program kerja dapat terlaksana adalah dengan strategi kooperatif, akomodasi (negosiasi, toleransi) dari pada harus menempuh strategi konfrontasi (konflik) dengan melakukan permusuhan.

\section{KESIMPULAN}

Organisasi kemahasiswaan yang biasa dikenal dengan Badan Eksekutif Mahasiswa (BEM) merupakan wadah kegiatan mahasiswa yang terikat dan diatur hak dan kewajibannya dalam Anggaran Dasar dan Anggaran Rumah Tangga dan dikuatkan oleh Surat Keputusan Rektor tersebut menjadi pelengkap keberadaan dan aktivitas kampus. Dinamika kampus tampak pada dinamika aktivitas organisasi kemahasiswaan dalam Badan Ekekutif Mahasiswa tersebut. Kegiatan Badan Eksekutif Mahasiswa tertuang dalam Program Kerja Organisasi (PROKER). Berbagai kendala yang dihadapi dalam 
melaksanakan program kerja tersebut. Kendala tersebut bisa datang dari diri pribadi (faktor kepentingan) baik yang terjadi pada pengurus BEM maupun mungkin pada pimpinan, bisa juga terjadi karena keterbatasan anggaran, sarana dan prasarana. Namun demikin semuanya bisa diatasi, melalui pendekatan kerjasama, negosiasi, dan akomodasi. Pendekatan ini harus dilakukan karena lembaga adalah pemegang anggaran tunggal, sehingga BEM tidak leluasa berinovasi karena berbagai keterbatasan yang ada.

\section{REFERENSI}

Bungin, Burhan. 2006. Sosiologi Komunikasi. Jakarta: Kencana

Flick, U. 2013. The SAGE handbook of qualitative data analysis. Sage.

Gunawan, Ary.H. 2010. Sosiologi Pendidikan. Jakarta: Rineka Cipta.

Keputusan Menteri Pendidikan dan Kebudayaan Republik Indonesia Nomor 155/U/1998. Tentang Organisasi Mahasiswa.

Kozicki, S. 2005. The creative negotiator. Tata McGraw-Hill Education.

Marwanto, I. H. 2018. Gaya Kepemimpinan Kepala Puskesmas. Mediasosian, Vol. 2(2), hal. 32-41.

Moleong, Lexy. 2014. Metode Penelitian Kualitatif, Edisi Revisi. PT Remaja Rosdakarya, Bandung.

Mujiarto, M., Susanto, D., \& Bramantyo, R. Y. 2019. Strategi Pelayanan Kesehatan Untuk Kepuasan Pasien Di UPT Puskesmas Pandean Kecamatan Dongko Kabupaten Trenggalek. Jurnal Mediasosian: Jurnal Ilmu Sosial Dan Administrasi Negara, 3(1).

Saldana. 2014. Qualitative Data Analysis, A Methods Sourcebook. UI-Press.

Tan, J. S., \& Lim, E. N. K. 2004. Strategies for Effective Cross-cultural Negotiation: The FRAME Approach. McGraw Hill New York.

Walgito, Bimo. 2003. Psikologi Sosial. Yogyakarta: Andi Offset.

Wulansari, Dewi. 2009. Sosiologi: Konsep Dan Teori. Bandung: PT Refika Aditama

Yanuarita, H. A., Hariyanto, \& Hanum, F. 2019. Pengaruh Pemberdayaan Dan Pembinaan Terkemuka Terhadap Kerja Karyawan Di Satuan Sabhara Polres Batu. Mediasosian, 3(1), hal. 1-14. 